\title{
Artificial Saliva Sorption for Three Different Types of Dental Composite Resin An in vitro Study
}

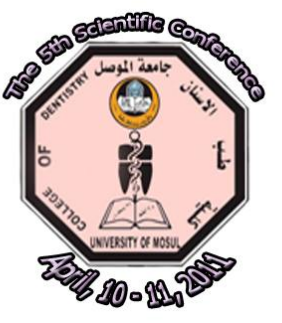

Aims: To evaluate the artificial saliva sorption for three different types of light activated composite resin. Materials and Method: A total of thirty six specimens (bars) $(3 \times 8 \times 15) \mathrm{mm}$ were prepared from three different types of light activated composite resin. (Tetric N-ceram, Iv o clar-vivadent-Liechtenstein. Arabesk - voco - Germany. Soltaire-2, Heraeus, kulzer, Germany). Twelve specimens were prepared from each type of composite resin. Complete fabrication of composite resin specimens, polished and kept in three different types of artificial saliva medium, three specimens from each type of composite resin as interactive specimens kept in type of artificial saliva and the last three specimens kept in Deionized water as control medium. The weight of each specimens was measured at an analytic balance before and after different time intervals of storage $(1,2,7,21,35,60)$ days to measure the amount of absorption of artificial Saliva (gaining and loss of weight). The study showed a significant difference $(\mathrm{P}<0.05)$ in artificial saliva sorption among the three different types of composite resin at different time intervals when kept in different artificial saliva medium. Tetric $\mathrm{N}$-ceram (nano composite) has more affect with three different types of artificial saliva medium (gaining and loss weight) followed by Arabesk, Soltaire-2 composite resin for different types of artificial saliva at different time intervals. Conclusion: Dental composites are sensitive to artificial salive medium (gain and loss of weight) Tetric $\mathrm{N}$ ceram (nano - composite) interact actively followed by Arabesk and Soltaire-2 for three different artificial saliva medium at different time intervals.

$$
\text { الخلاصة }
$$

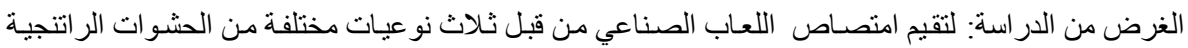

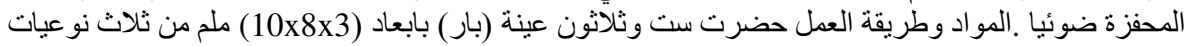

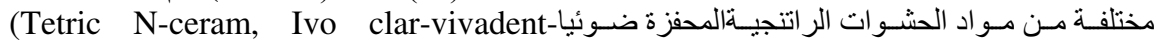
Liechtenstein. Arabesk - voco - Germany. Soltaire-2, Heraeus, kulzer, Germany). عشر عينة (بار) تم تحضير ها من كل نوعية من مو اد الحشو ات الر التنجية المحفزة ضونئيا. تم تحضير مختبري

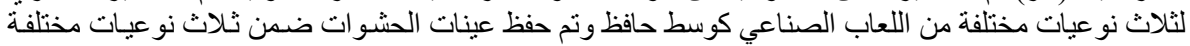

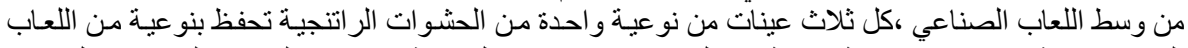

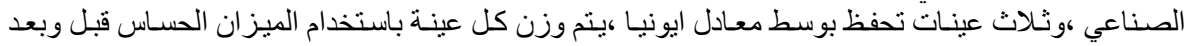

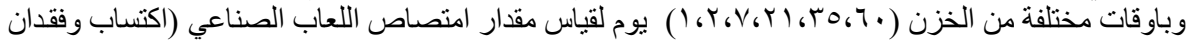

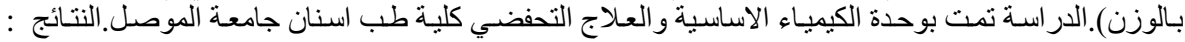

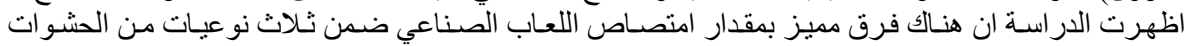

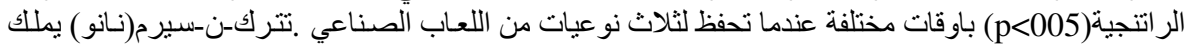

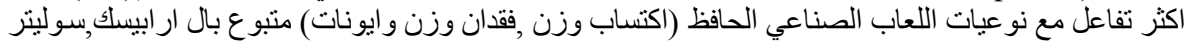

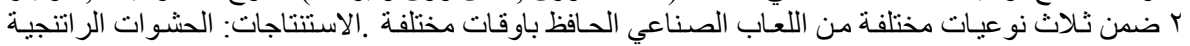

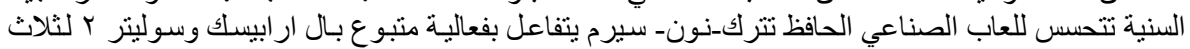
نو عيات مختلفة من اللعاب الصناعى وباع لناوقات مختلفة.

Department of Dental Basic Science, College of Dentistry, University of Mosul. Department of Conservative Dentistry, College of Dentistry, University of Mosul

Key word: Artificial saliva, sorption, Dental composite.

\section{INTRODUCTION}

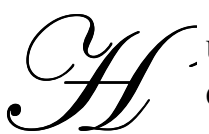

uman saliva consists of water, glycoproteins, enzymes, antimicrobial substance and electrolyte. Biophysical point of view saliva is a viscoelastic fluid with distinct surface activity. Commercial saliva, artificial saliva used in salivary gland disorders should resemble normal saliva in biophysical properties ${ }^{(1)}$.

Restorative fillings materials used in dentistry are required to have long term durability in the oral cavity. This is a complex environment where the materials is in contact with saliva , 
fluid that contains avaritey of inorganic and organic species, togather with a bacterial flora complex ${ }^{(2)}$.

Composite is a heterogenous material that is composed from three major components (resin matrix, filler particles and silane coupling agent ${ }^{(3) \text {. }}$

Since 1960 dental composite introduced in dentistry, they have undergone a lot of changes in order to became a restorative material with acceptable properties ${ }^{(4)}$.

The interaction of these restorative materials with oral fluid may involve dissolution or degradation of surface layers whiles in others the interaction may involve a leaching out of unbound or loosely bound components or an up take of fluids into the structure of material.

Such fluid absorption may affect the mechanical properties of the materials and cause damaging and dimensional changes ${ }^{(5)}$.

Polymer nano particles composite resin have attracted the interest of a number of researchers, due to their synergistic and hybrid properties derived from several components. Whether in solution or in bulk, these materials offer unique mechanical. Tribiological, electrical, optical, and thermal properties ${ }^{(6,7) \text {. }}$

Such enhancements are induced by the physical presence of the nano particle and by the interaction of the polymer with the particle and the state of dispersion ${ }^{(6,7)}$.

Dental composite materials reinforced with particles that usually have dimensions in the range of 0.04-10 micro meters. According to Wetzel et al, Wetzel, and vaia et al, particles favorably stiffen the material and may also increase the strength under certain load conditions but on the other hand, it has to be considered that they yield a detrimental effect on the important properties, e.g. the materials resistance against impact and fracture toughness. A new approachaiming to over come this basic problem is related to the nana technology and uses fillers in nanometer scale ${ }^{(8,9,10)}$.

Recent advancement indirect dental restorative material at time of change for dental composite formulation as evidenced by the arrival of new composite formulation reinforced by "nano and micro fillers" dental restorative material in which materials composed of nanometric and micrometric inorganic particles as reinforcing filers e.g. Esthex-Dentsply.

\section{MATERIALS AND METHODS}

The Study was carried out in the Department of Dental Basic Sciences and Conservative Dentistry, College of Dentistry, University of Mousl.

A total of thirty six specimens (bars) at dimension of $(3 \times 8 \times 15) \mathrm{mm}$ were prepared from three different types of light activated composite resin as show in Table (1) and Figure (1) include three groups:

Group I: Twelve specimens where prepared from light activated nanohybride composite resin (Tetric N-ceram, Ivoclar - vivadent - Liechtenstein).

Group II: Twelve specimens were prepared from light activated microhybride composite (Arabesk, voco - Germany).

Group III: Twelve specimens where prepared from light activated polyglass hybrid composite (Soltaire-2) composite, Heraus, kulzer, Germany. 
Table (1) Composition of three different type of light curing composite resin

\begin{tabular}{|c|c|c|c|}
\hline $\begin{array}{l}\text { Type of } \\
\text { composite resin }\end{array}$ & composition & Particle size & Manf. \\
\hline TetricN-ceram & $\begin{array}{l}\text { Dimethacrylates }(19-20 \mathrm{wt} \%) \\
\text { barium glass ytterbium trifluoride } \\
\text { mixedoxide, copolymer }(80-81) \\
\text { wt } \% \text { catalysts, stabilizer and } \\
\text { pigments }(<1 \text { wt } \% \text { inorganic filler } \\
55-57 \text { vol } \%)\end{array}$ & $40 \mathrm{~nm}-3000 \mathrm{~nm}$ & Ivoclar vivadent \\
\hline Arabesk & $\begin{array}{l}60 \% \text { by volum ( } 76.5 \% \text { by weight) } \\
\text { inorganic fillers micro fliers } 0.05 \mu \mathrm{n} \\
\text { small particle fillers } 0.5-2 \mu \mathrm{n}\end{array}$ & $\begin{array}{l}0.05 \mu \mathrm{n} \\
0.5-2 \mu \mathrm{n}\end{array}$ & Voco-Germauy \\
\hline Soltaire -2 & $\begin{array}{l}\text { Mutticroos-linking urethane (meth) } \\
\text { acrylatemonomers } \\
* \text { BaAF-Silicateglass } \\
* \text { Porous-Silic on dioxide }\end{array}$ & $\begin{array}{l}0.02-23 \mu \mathrm{n} \\
\varnothing 0.7 \mu \mathrm{n} \\
\operatorname{Max}<2 \mu \mathrm{n} \\
\varnothing 8 \mu \mathrm{n}, \max \\
(23) \mu \mathrm{n}\end{array}$ & Heraeus-kulzer \\
\hline
\end{tabular}

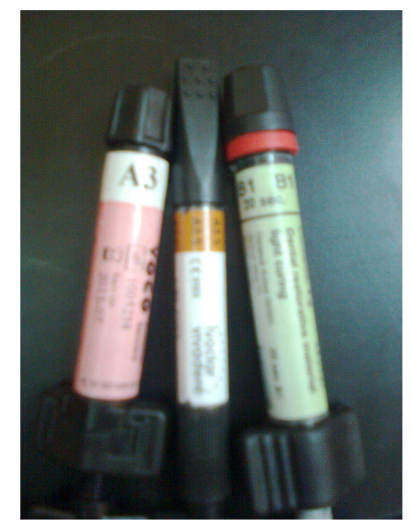

Figure (1) Three different types of dental composite used in this study.

Specimens for each tested materials $(3 \times 8 \times 15) \mathrm{mm}$ were fabricated from larger bars with dimensions of $(3 \times 8 \times 30) \mathrm{mm}$ the composite materials were polymerized in a silicon mold made from acrylic bars to produce the larger bars after that they were cut in two part to produce the specimens, the specimens were produced in horizontal layers and pressed with spatula to prepare the bars two layers were necessary due to their thickness(11) materials were manipulated according to manufacture's instructions .

Specimens were polymerized using a light curing unit (Monitex- Tawan-08H0153) inside the silicon mold, each layer was photo-polymerized during forty second, doubling the recommended time to ensure complete polymerization, the distance between the light source and specimens was standardized $(1.35 \mathrm{~mm})$.

The light intensity $(500 \mathrm{~nm})$ of the curing light was checked regularly, during specimens preparation and after wards. Specimens were polished to remove the imperfection as shown in Figure (2). 


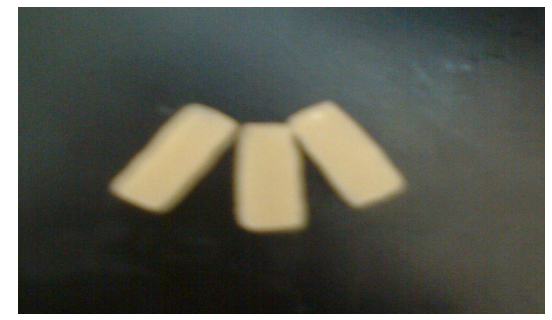

Figure (2) Dental composite specimens used in this study.

Within each group, specimens kept in three different types of artificial saliva as shown Table (2), three specimens from each type of composite kept in type of artificial saliva medium, and the last three specimens kept in deionized water as control group $37^{\circ} \mathrm{C}^{(11)}$.

Table (2) Chemical composition of 3 different artificial saliva mediums.

1- Artificial saliva composition (12) type (1)

$\begin{array}{cc}\text { Component's } & \begin{array}{c}\text { Concentration } \\ (\mathrm{glL})\end{array} \\ \mathrm{NaCl} & 0.40 \\ \mathrm{KCl} & 0.40 \\ \mathrm{CaCl}_{2} \cdot 2 \mathrm{H}_{2} \mathrm{O} & 0.795 \\ \mathrm{NaH}_{2} \mathrm{PO}_{4} \cdot 2 \mathrm{H}_{2} \mathrm{O} & 0.780 \\ \mathrm{Na}_{2} \mathrm{~S}_{9} \mathrm{H}_{2} \mathrm{O} & 0.005 \\ \mathrm{CO}\left(\mathrm{NH}_{2}\right)_{2} \text { (Urea) } & 1.0 \\ \text { Distilled water } & 1000 \mathrm{ml}\end{array}$

2- Artificial saliva composition (11) type (2)

Components

$\mathrm{NaCl}$

$\mathrm{KCl}$

$\mathrm{KSCN}$

$\mathrm{KH}_{2} \mathrm{PO}_{4}$

Ureia

$\mathrm{Na}_{2} \mathrm{SO}_{4}, 10 \mathrm{H}_{2} \mathrm{O}$

$\mathrm{NH}_{4} \mathrm{Cl}$

$\mathrm{CaCl}_{2}, 2 \mathrm{H}_{2} \mathrm{O}$

$\mathrm{NaHCO}_{3}$

3- Artificial saliva composition(1) type (3)

Component

Zanthangum

Potassium chloride

Sodium chloride

Magnesium chloride

Calcium chloride Di-Potassium

Sodium di-hydrogen phosphate

Methyl-polyhydroxy Benzoate

Concentration $\mathrm{mg} / \mathrm{ml}$
125.6
963.9
189.2
654.5
200.0
763.2
178.0
227.8
630.8

Concentration

$\mathrm{g} / \mathrm{l}$

0.92

1.2

0.85

0.05

0.13

0.13

0.35

Journal of the $5^{\text {th }}$ Scientific Conference of Dentistry College, Apr. 2011 
The weight of each specimen was measured at an analytical Balance before and after storage at different time intervals 1, 2, 7, 21, 35, 60 days to measure the amount of absorbed of artificial saliva.

\section{RESULTS}

Statistical analysis of one way ANOVA and Duncan Multiple Range Test for artificial saliva sorption showed a significant difference $(\mathrm{P}<0.05)$ among three different types of light activated composite resin. The results showed (gain and loss) in their weight as a result of being immersed in three different types of artificial saliva medium and deionized water.

Tetric N-ceram (nano composite) showed gain and loss in their weight (0.014 gram) interact actively compared to Arabesk (0.027 gram) and Soltaire-2 (0.032 gram) composite resin which showed minor loss in their weight as shown in Table(3).

Table (3) ANOVA and Duncan's Multiple Range Tests for the artificial saliva sorption (gram) for three different types of dental composite resin.

\begin{tabular}{|c|c|c|c|c|c|}
\hline Composite resin & $\begin{array}{c}\text { Number } \\
\text { of } \\
\text { specimens }\end{array}$ & $\begin{array}{c}\text { Mean } \\
\text { (gram) }\end{array}$ & $\begin{array}{l}\text { Standard } \\
\text { deviation }\end{array}$ & $P$ - value & $\begin{array}{c}\text { Duncan's } \\
\text { group }\end{array}$ \\
\hline Tetric N - Ceram & 12 & 0.014 & 0.006 & 0.000 & A \\
\hline Arabesk & 12 & 0.027 & 0.018 & 0.000 & B \\
\hline Soltaire-2 & 12 & 0.032 & 0.020 & 0.000 & $\mathrm{C}$ \\
\hline
\end{tabular}

Different letters mean significant difference at $\mathrm{P}<0.05$.

There are significance difference $(\mathrm{P}<0.05)$ in artificial saliva sorption for three different groups compare to control group in which minor gain in weight for three different types of composite (0.01) in deionized water compared to saliva type (3), (1) and (2) which differ in chemical composition Table(4).

Table (4) ANOVA and Duncan's Multiple Range Tests for three different types of artificial saliva and deionized water.

$\begin{array}{cccccc}\text { Medium } & \begin{array}{c}\text { Number of } \\ \text { specimens }\end{array} & \begin{array}{c}\text { Mean } \\ \text { (gram) }\end{array} & \begin{array}{c}\text { Standard } \\ \text { deviation }\end{array} & \begin{array}{c}\text { P - value } \\ \text { Duncan's } \\ \text { group }\end{array} \\ \text { Saliva 1 } & 12 & 0.027 & 0.015 & 0.000 & \text { C } \\ \text { Saliva 2 } & 12 & 0.034 & 0.023 & 0.000 & \text { D } \\ \text { Saliva 3 } & 12 & 0.020 & 0.013 & 0.000 & \text { B } \\ \text { deionized } & 12 & 0.010 & 0.004 & 0.000 & \text { A } \\ \text { water } & & & & & \end{array}$

Different letters mean significant difference at $\mathrm{P}<0.05$.

The first day of storage in artificial saliva medium showed significant difference $(\mathrm{p}<0.05)$ about gain in weight, (increase in weight until 7 days). After 21 days of storage, there are decrease in weight (loss of weight) for the three types of composite specially with Tetric $\mathrm{N}-$ Ceram, Arabesk and Soltaire-2 composite resin as shown in Table (5). 
Table (5) ANOVA and Duncan's Multiple Range Tests for artificial saliva sorption (gram) for thre different types of composite resin at different time intervals.

\begin{tabular}{|c|c|c|c|c|c|}
\hline Time & $\begin{array}{l}\text { Number of } \\
\text { specimens }\end{array}$ & $\begin{array}{l}\text { Mean } \\
\text { (gram) }\end{array}$ & $\begin{array}{l}\text { Standard } \\
\text { deviation }\end{array}$ & $\mathrm{P}$ - value & $\begin{array}{l}\text { Duncan's } \\
\text { group }\end{array}$ \\
\hline 1 day & 12 & 0.019 & 0.011 & 0.000 & B \\
\hline 2 days & 12 & 0.026 & 0.018 & 0.000 & $\mathrm{E}$ \\
\hline 7 days & 12 & 0.038 & 0.026 & 0.000 & F \\
\hline 21 days & 12 & 0.025 & 0.017 & 0.000 & $\mathrm{D}$ \\
\hline 35 days & 12 & 0.021 & 0.009 & 0.000 & $\mathrm{C}$ \\
\hline 60 days & 12 & 0.015 & 0.008 & 0.000 & A \\
\hline
\end{tabular}

Different letters mean significant difference at $\mathrm{P}<0.05$.

\section{DISCUSSION}

Artificial saliva sorption and water sorption may cause some undezirable effect such as softening of the resin matrix, resin degradation, reduction of stain - resistance and leakage of filler elements by degradatioy of silane present in the interface between matrix and particles ${ }^{(13,}$

Dental composite (nano, micoparticles) are sensitive to the three different type of artificial saliva medium at different time intervals.

The gain and loss of weight for nano composite (Tetric N-cream) was significantly differ from than micro (Arabesk) and (Soltaire-2) composite resin. This due to its diffusion coefficient was higher than other (Arabesk and Solitarine-2) composite resin.

Nano composite gain and loss more components (particles) than micro composites because it is particles are smaller than other types. A number of factors will determine the diffusion coefficient for this type of materials (nano, microcomposite) these include, the type of resin filer fraction, filler size reactivity of the glass, and the presence of silane and nano silane coupling agents ${ }^{(13,15) \text {. }}$

The diffusion coefficient of nano composite was higher than micro composite. This is due to higher exchange of substance between artificial saliva and composite material (nano particle). Tertric $\mathrm{N}$ - ceram (nano composite) has more interaction with artificial saliva medium (gaining and loss of weight) compared to other nano composite which has highest loss of components. It also justified its final smallest gain of weight. Nano composite has smaller particles than microcomposite. Nano composite have higher specific surface area than micro composite, the nano-composites may loose filler elements by degradation of the silane present in the interface between matrix and particles, nano composite loss of weight (lost more particles) because it has more interface area covered with silane to be degraded ${ }^{(13,16)}$.

For three different types of composite the weight increase due to absorption of artificial saliva at time from first day of immersion in artificial saliva medium until 7th day, after 21th day of storage in artificial saliva, the interaction between artificial saliva and composite materials become smaller specially (gaining of water), and looss more amount of weight and ions specially for nano composite .

Water sorption by composite stored in deionized water during different periods of storage are lowest than artificial saliva medium because artificial saliva stored medium promotes more interaction of materials with artificial saliva than deionized water ${ }^{(17,18) .}$ 


\section{CONCLUSIONS}

Dental composites are sensitive to artificial saliva medium, gain and loss of weight of Tertric N - ceram (nano - composite) may interact actively followed by Arabesk and Soltaire-2 composite for three different types of artificial saliva at different time intervals.

\section{REFERENCES}

1. Preetha A, Banjee R. Comparison of Artificial Saliva Substitutes, Trends Biomater. Artif Organs. 2005, 18 (2):1322.

2. Okada S. surface hardness change of restorative filling materials stored in saliva, Dental Materials J. 2001, 17: 14-39.

3. Senawonges P, Pongoruek F surface roughness of nanofill and nanohybrid resin composites after polishing and brushing. J Esthet restor Dent. 2007, 19: 265-275.

4. Papadogiamis T, Papadogiaunisy. The effect of temperature change on the viscoelastic properties of nanohybrid composite. J Dent Mater. 2008, 24: 257-266.

5. Mccabe TJ, Rusby S. water absorption, dimensional change and radial pressure in resin matrix dental restorative materials. Biomaterials J. 2004, 19: 91-96.

6. Schmidt G., Malwitz M. , properties of polymer - nano particles composites. J Current Opinion in Colloid and Interface Science. 2003, 8 (1): 103-108.

7. Krishnamortir R, Via RA. Polymer nano-composites. J Mater Chem. 2002, 2(12): 1219-30.

8. Wetze B. "Impact and wear resistance of polymer nano-composites at low filler content. J Eng Sci. 2002,42 (9): 1919-27.

9. Wetzel B. Haupert F. Zhang M "Nano composites with high mechanical and tribological performance". Composites Science and Technology J. 2003, 63: 2055-2067.

10. Via RA, Beayson Telle T., Schmitt G-Nano science and technology: materials revolution for the 21 st century". Sampe J. 2001, 37 (6) 24-31.

11. Mayworm CD, Leao MH, Bastianfl, Artificial saliva sorption for two hybrid nano particle resin based restorative dental composites. J. Enpromer. 2005, 4(2): 41-52.

12. Ohtaek kand kimKN. Ion release and cytotoxicity of stainless steelwires. Eur J orthod. 2005. 27: 533-540.

13.Marthin M, Jectynakiewic M. , Fisher CA. Hygroscopic expansion and solubility of composite restorative materials. J Dent materials. 2003; 19: 77-86.

14.Musanje D. Dravell BW: aspects of watersoption from the air, water and artificial saliva in resin composite restorative material. J Dent Material. 2003; 19: 414-422.

15.Beathy MW, Effect of micro filler fraction and silane treatment on resin composite properties. $J$ Biomed Mater Res. 1998; 40:12-23.

16.Musanjel, Barvell BW. Aspects of water sorption from the air, water and artificial saliva in resin composite restorative materials. J Dent Mater. 2003, 19: 414-422.

17.McCabe JF Rusbs S water absorption dimensional change and radial pressure in resin matrix dental restorative materials. Biomaterials J. 2004; 6: 91-100.

18. Silverstre FJ, minguez MP, Sunnegrej. clinical evaluation of new artificial saliva in spray form for patients with dry mouth. Med Oral Patol Oral Cir Bucal. 2009, 14(1): 8-11. 